\title{
CZEMU SŁUŻY PROGRAM RODZINA 500 PLUS? ANALIZA CELÓW POLITYKI PUBLICZNEJ I POLITYKI PARTYJNEJ
}

\section{WPROWADZENIE}

Rodzina 500 plus (Rodzina 500+) to najdroższy w III RP instrument polityki rodzinnej. Świadczenie w wysokości 500 złotych miesięcznie przysługuje bez kryterium dochodowego na drugie i każde kolejne dziecko do 18 roku życia oraz na pierwsze dziecko w rodzinach, w których dochód netto w przeliczeniu na osobę nie przekracza $800 \mathrm{zł}^{1}$. Według danych na styczeń $2018 \mathrm{r}$. świadczeniem zostało objętych 3,68 mln dzieci wychowujących się w 2,41 mln rodzin. Przy założeniu stałej liczby beneficjentów program w $2018 \mathrm{r}$. będzie kosztował $22,1 \mathrm{mld}$ zł - co szesnastą złotówkę wpływającą do budżetu Polski². Jeszcze przed jego wejściem w życie w 2016 r. program znało pięć razy więcej osób (79\%) niż drugi projekt flagowy rządu PiS - tzw. Planu Morawieckiego (15\%)3. Rodzina 500+ tym się różni od wielu innych programów publicznych, że głęboko przeniknął do powszechnej świadomości, co może wynikać z wysokości świadczenia, jego prostoty, nagłośnienia medialnego i poczucia, że polityka ta bezpośrednio wpływa na los ludzi.

Jednak mimo tak znacznego dotarcia do społeczeństwa, bezprecedensowych kosztów oraz skali oddziaływania, panuje konfuzja odnośnie do tego, co program ma osiagnaćc. Niniejszy artykuł analizuje cele programu jako polityki publicznej - widoczne w legislacji, komunikacji medialnej oraz zaplanowanym sposobie ewaluacji - a następnie cele programu z punktu widzenia polityki partyjnej. Pierwsza część tekstu skupia się na celach zaprezentowanych w procesie legislacyjnym i spodziewanym sposobie ewaluacji. Zastosowana metoda to analiza społeczno-ekonomiczna wszystkich dokumentów dotyczacych ustawy o pomocy państwa w wychowaniu dzieci dostępnych na stronie Sejmu oraz Rządowego Centrum Legislacji (RCL). Druga część artykułu skupia się na medialnych wypowiedziach rządzących. Na podstawie pełnionej funkcji w mo-

\footnotetext{
${ }^{1}$ Lub $1200 \mathrm{zł}$ w przypadku dziecka niepełnosprawnego.

${ }^{2} \mathrm{~W}$ budżecie Polski na 2018 r. przewidziano wpływy w wysokości $355,7 \mathrm{mld}$ zł. Oznacza to, że program będzie stanowił 1116 tej kwoty.

${ }^{3}$ CBOS, Program „Rodzina 500 plus” jako element systemu wspierania rodzin i dzietności. Komunikat z badań nr 25/2016, Warszawa 2016; CBOS, Recepcja Planu na rzecz Odpowiedzialnego Rozwoju. Komunikat z badań nr 44/2016, Warszawa 2016.
} 
mencie wejścia ustawy w życie (11 lutego 2016 r.) identyfikuję sześciu najważniejszych polityków związanych z obozem rządzącym oraz trzy najważniejsze osoby w ministerstwie odpowiedzialnym za realizacje programu, a następnie analizuję ich wypowiedzi na temat celów programu. Trzecia część artykułu konfrontuje cele zidentyfikowane $\mathrm{w}$ mediach i legislacji z celami polityki partyjnej, które pomaga osiagać cel programu.

\section{CELE POLITYKI PUBLICZNEJ: ANALIZA LEGISLACJI ${ }^{4}$}

Z punktu widzenia jakości polityki publicznej cele powinny być klarownie sformułowane w legislacji, wyjaśnione i poparte badaniami w uzasadnieniu ustawy, mierzalne, skonsultowane z obywatelami i czytelnie zakomunikowane przez rządzących. W pierwszej części artykułu analizowane jest uzasadnienie ustawy oraz ocena skutków regulacji - czyli dokumenty, które powinny przedstawiać diagnoze problemu, cel oraz oczekiwany efekt regulacji - oraz konsultacje publiczne i ustalenia międzyresortowe, czyli te elementy procesu legislacyjnego, w których powinniśmy widzieć jakość dialogu z obywatelem i współgranie z innymi organami państwa wokół wybranego celu (schemat 1).

\section{Ocena skutków regulacji}

Ocena skutków regulacji (OSR) służy przedstawieniu konsekwencji proponowanej legislacji na wybrane obszary, takie jak finanse publiczne czy rynek pracy. Projekt OSR do Rodziny 500 plus opublikowano 2 grudnia 2015 r. - zaledwie dziesięć dni roboczych po exposé premier Beaty Szydło, które dokument przedstawia jako źródło proponowanej regulacji. Według projektu OSR legislacja „ma na celu przede wszystkim pomoc dla rodzin wychowujących dzieci oraz przeciwdziałanie spadkowi demograficznemu" .

Już w pierwszym zdaniu projektu pojawia się problem z identyfikacją celu: nie wiadomo, czym jest spadek demograficzny. Możemy zakładać, że projektodawcy chodzi o ujemny przyrost naturalny lub spadek współczynnika dzietności. Precyzja koncepcyjna jest kluczowa w polskiej sytuacji, w której wskaźniki te przez ostatnie lata oddziaływały w przeciwnych kierunkach: od lat sześćdziesiątych spadek współczynnika dzietności (TRF) zanotowano aż 35 razy $^{6}$, podczas gdy przyrost naturalny, dzięki szybko rosnącej długości życia, był dodatni przez cały ten czas z wyjątkiem lat 2005 i $2013-2015$.

${ }^{4}$ Bardziej szczegółowa analiza zagadnień z tego podrozdziału jest dostępna w popularnonaukowym opracowaniu autorki: A. Gromada, Rodzina 500+ jako polityka publiczna, Instytut Studiów Zaawansowanych, Warszawa 2017.

${ }^{5}$ Projekt Oceny Skutków Regulacji (2.12.2015), <http://legislacja.rcl.gov.pl/docs//2/12279566 /12326791/12326792/dokument199002.pdf>.

${ }^{6}$ W ciagu ostatnich 55 lat jedynie 15 razy (w latach 1971, 1973, 1975-1976, 1979, 1982-1983, 1991 i 2004-2010) zanotowano małe odbicia we współczynniku dzietności; 5 razy współczynnik dzietności pozostawał stabilny i aż 35 razy spadał (obliczenia własne na podstawie bazy danych Banku Światowego 2016). 
Następnie czytamy, że „wraz z postępującym spadkiem demograficznym powiększa się liczba osób żyjących w ubóstwie ekonomicznym”. Nie wiemy jednak, o jakie ubóstwo chodzi ani w jakim horyzoncie czasowym. W tym przypadku nie chodzi jednak wyłącznie o precyzję metodologiczna, ale o zamieszczanie informacji, które są nieprawdziwe. Jeśli przyjmiemy ostatnią dekadę za horyzont czasowy, widzimy, że s p a dły wszystkie trzy wskaźniki ubóstwa: ubóstwo ustawowe, ubóstwo relatywne i ubóstwo skrajne (zob. wykres 1). Jeśli zaś przyjąc za horyzont czasowy ostatnie dane dostępne w momencie tworzenia dokumentu - czyli porównanie roku 2013 z 2014 - widzimy stabilizację ubóstwa skrajnego (na poziomie 7,4\%), stabilizację ubóstwa relatywnego (na poziomie $16,2 \%$ ) i spadek ubóstwa ustawowego z $12,8 \%$ do $12,2 \%$.

\section{Wykres 1}

Ubóstwo ekonomiczne w Polsce w 2014 r. (jako \% osób w gospodarstwach domowych)

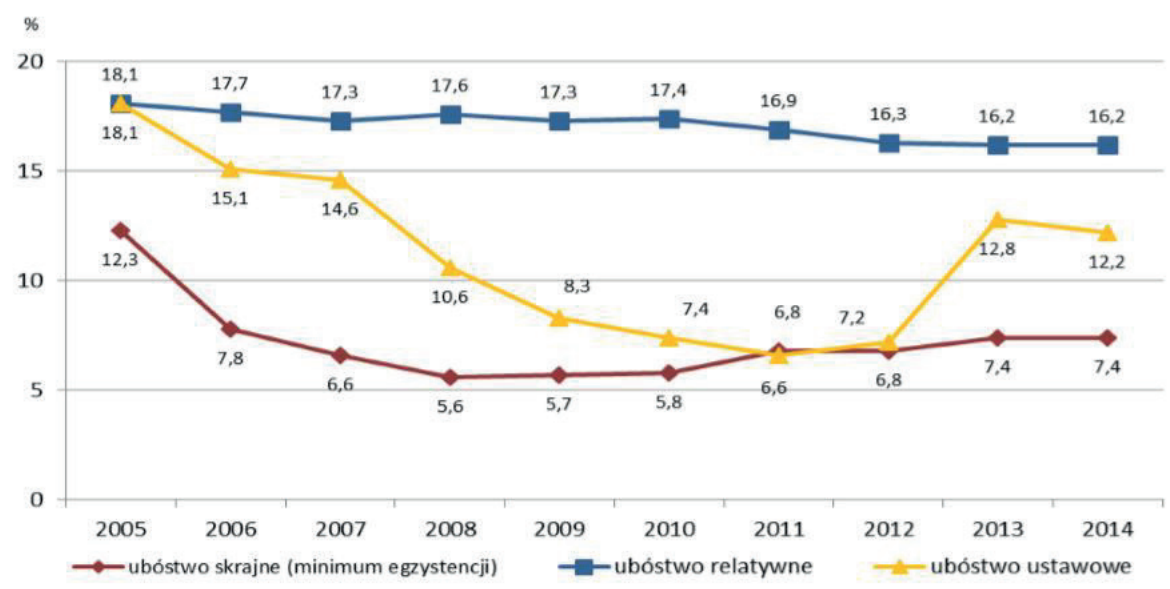

Źródło: GUS, Ubóstwo ekonomiczne w Polsce w 2014 r. (na podstawie badania budżetów gospodarstw domowych), Warszawa 2015.

W świetle deklarowanego celu, jakim jest walka z ubóstwem, należy zadać pytanie o skuteczność i sprawiedliwość społeczną proponowanego mechanizmu. Ustanawiając próg na 800 zł netto na osobę, który jest niższy niż minimum socjalne, wykluczamy z niego osoby o wyjątkowo niskich dochodach. Nawet osoba pracująca za płacę minimalną na podstawie umowy zlecenia i samotnie wychowująca jedno dziecko jest poza zasięgiem programu, gdyż w jej rodzinie dochód na osobę wyniesie 886 zł netto7. Przykład ten pokazuje co najmniej dwa problemy związane z programem Rodzina 500+. Po pierwsze,

${ }^{7}$ W 2018 r. płaca minimalna wyniosła 2100 zł brutto. W przypadku umowy zlecenia na taka kwotę po odliczeniu 189 zł (ubezpieczenie zdrowotne) i 140 zł (zaliczka na PIT) kwota netto wyniesie $1771 \mathrm{zł}$. 
wykluczeni są z niego względnie biedni rodzice jedynaków, podczas gdy świadczenie obejmie wielodzietnych zamożnych, dlatego trudno uznać, że celem programu jest walka z ubóstwem. Po drugie, progowe wycofywanie świadczenia ${ }^{8}$ prowadzi do następującego paradoksu: gdyby wspomnianemu pracownikowi obniżyć pensję o 171 zł netto, otrzymałby 500 zł świadczenia, przez co jego ogólny dochód wyniósłby 2100 zł netto - czyli o 329 zł więcej niż obecnie. Takie rozwiązanie legislacyjne może zachęcać osoby na granicy progu dochodowego do sztucznego zaniżania swoich wynagrodzeń przez nierejestrowanie części dochodu. Może to przyczyniać się do wzrostu szarej strefy - szacowanej dziśs w Polsce na $18 \%{ }^{9}$.

\section{Schemat 1}

Cele programu Rodzina 500+ w procesie legislacyjnym

Projekt oceny skutków regulacji (2 grudnia 2015) i Ocena skutków regulacji (29 stycznia 2016)

Cel: „pomoc dla rodzin wychowujących dzieci oraz przeciwdziałanie spadkowi demograficznemu".

Uzasadnienie ustawy (22 grudnia 2015)

„Celem projektowanej ustawy jest przede wszystkim pomoc finansowa

kierowana do rodzin wychowujących dzieci. Proponowane rozwiązanie ma

zmniejszyć obciążenia finansowe rodzin związane $\mathrm{z}$ wychowywaniem dzieci,

a tym samym zachęcać do podejmowania decyzji o posiadaniu większej liczby

dzieci”.

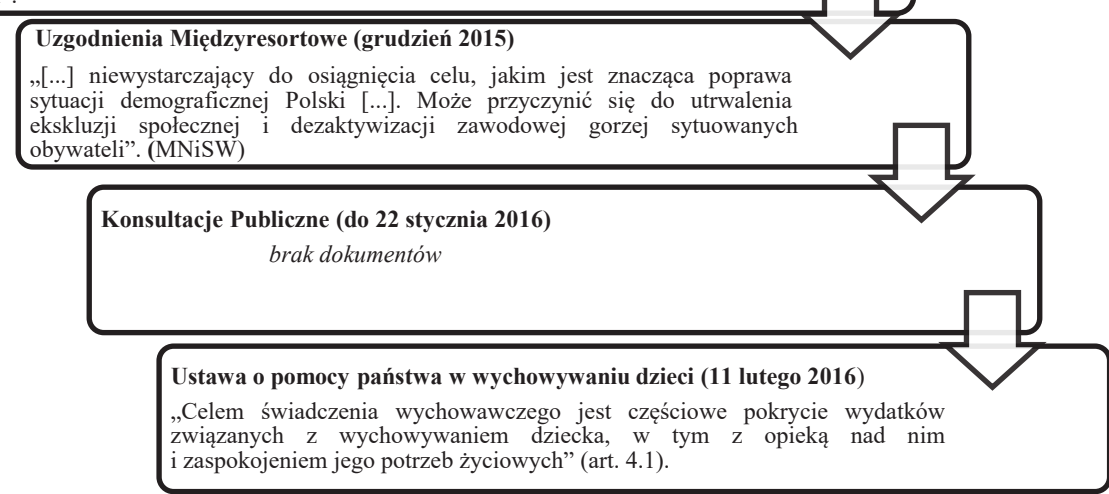

Źródło: opracowanie własne.

Twórcy programu zaznaczają jego oddziaływanie na gospodarkę, jednakże działanie przewidziane w projekcie OSR z 2 grudnia 2015 r. jest odwrotne od działania przewidzianego w OSR z 29 stycznia 2016 r. Według pierwszego

${ }^{8}$ Progowe wycofywania świadczenia oznacza, że po przekroczeniu progu dochodowego, nawet o 1 zł, całkowicie traci się prawo do jego otrzymania.

9 J. Fundowicz, K. Łapiński, B. Wyżnikiewicz, Szara Strefa 2018, Instytut Prognoz i Analiz Gospodarczych, Warszawa 2017. 
z tych dokumentów Rodzina 500+ ma oddziaływać na sektor przedsiębiorstw przez zwiększoną konsumpcje gospodarstw domowych, co ma prowadzić do wzrostu zatrudnienia o 65 tys. etatów w gospodarce oraz około 7 tys. etatów w związku z realizacją ustawy. Jednak już w OSR ze stycznia spodziewany kierunek wpływu na rynek pracy jest odwrotny: transfery pieniężne mają spowodować obniżenie podaży pracy - zwłaszcza wśród kobiet. Co istotne, w tym drugim scenariuszu ustawodawca nie oszacował wielkości zjawiska (co zrobili np. analitycy CenEA) ${ }^{10}$.

\section{Uzasadnienie ustawy}

Uzasadnienie ustawy powinno przedstawiać diagnozę problemu, z jakim mierzy się legislacja, jej cel oraz poparte badaniami uzasadnienie, jak proponowane narzędzia mają doprowadzić do jego realizacji. W uzasadnieniu ustawy o 500+ jest on jasno określony: „celem projektowanej ustawy jest przede wszystkim pomoc finansowa kierowana do rodzin wychowujących dzieci”. Problem tkwi jednak w następujaccym po nim wnioskowaniu: „proponowane rozwiązanie ma zmniejszyć obciążenia finansowe rodzin związane $\mathrm{z}$ wychowywaniem dzieci, a tym samym zachęcać do podejmowania decyzji o posiadaniu większej liczby dzieci”. Implikacja ta sugeruje, że pieniądze idą w parze z większą liczbą dzieci i że transfery finansowe - ceteris paribus - doprowadzą do wzrostu dzietności.

Takie jakoby intuicyjne rozumowanie jest problematyczne i stoi $\mathrm{w}$ sprzeczności z doświadczeniem innych krajów europejskich. Transfery do rodzin moga wpływać pozytywnie na zdrowie, wyniki szkolne czy dochody w przyszłości ${ }^{11}$, ale ich wpływ na dzietność jest w najlepszym razie niejednoznaczny. Dzietność jest skomplikowanym zjawiskiem - jego korelaty zmieniają kierunek w czasie zarówno w tych badaniach, w których jednostka analizy jest państwo, jak i w tych, w których jednostką analizy jest człowiek. Do lat osiemdziesiątych kraje rozwinięte $\mathrm{z}$ wysoką proporcją wykształconych i pracujących kobiet były jednocześnie krajami o niskiej dzietności, jednakże w latach dziewięćdziesiątych ta relacja stała się pozytywna ${ }^{12}$. Nowe badania nad uwarunkowaniami dzietności: porównania międzynarodowe ${ }^{13} \mathrm{i}$ badania polskie (np. Ireny Kotowskiej, Anny Matysiak czy Anny Kurowskiej), wskazuja, że kobiety, szczególnie te z wyższym wykształceniem, są ukierunkowane na zatrudnienie, które dla wielu z nich warunkuje posiadanie dziecka. Z kolei badania Generacje i Rodziny (GGS-PL) pokazuja, że pieniądze nie mają tak dużego znaczenia dla planowania decyzji o pierwszym i kolejnym dziecku w perspektywie trzech lat. Na decyzje o urodzeniu pierwszego dziec-

${ }^{10}$ Por. M. Myck, Estimating Labour Supply Response to the Introduction of the Family 500+ Programme, Szczecin 2016.

${ }_{11}$ A. Aizer et al., The long-run impact of cash transfers to poor families, „The American Economic Review” 106(4), 2016, s. 935-971.

12 J. Sleebos, Low Fertility Rates in OECD Countries: Facts and Policy Responses, Paris 2003.

${ }^{13} \mathrm{~Np}$. G. Esping-Andersen, Incomplete Revolution: Adapting Welfare States to Women's New Roles, Cambridge 2009. 
ka ma natomiast wpływ posiadanie własnego mieszkania oraz pracy przez oboje partnerów.

W całym uzasadnieniu ustawy nie znajdziemy ani jednego zdania na poparcie tezy, że pieniądze zachęcają do posiadania dzieci. Nie przedstawiono diagnozy uzasadniającej, że przez planowaną politykę cel zostanie osiagnięty, przez co nie można zaliczyć Programu 500+ do polityki opartej na faktach. Uzasadnienie nie analizuje dotychczasowych rozwiązań w obszarze interwencji ani nie zastanawia się nad lukami (ciagłość polityki), ani też nie zapewnia synchronizacji programu z dotychczasowymi narzędziami (komplementarność). Co ważniejsze, nie rozważa, jakie inne instrumenty (albo współdziałanie różnych instrumentów - tzw. policy mix) wpłynęły na dzietność w innych krajach rozwiniętych. Byłoby to szczególnie ważne w Polsce, która ma jeden z najwyższych na świecie odsetków kobiet z wykształceniem wyższym, co zwykle przekłada się na silną orientację zatrudnieniowa.

Jedynym miejscem, w którym ustawodawca szuka związków dzietności z innymi dziedzinami życia społeczno-ekonomicznego, jest odwrotna korelacja między stopą bezrobocia a dzietnością w latach 2000-2014. Powołuje się na opracowanie prof. Kotowskiej mówiące, że na niską dzietność wpłynęły zmiany na rynku pracy, zagrożenie bezrobociem lub wzrost aspiracji edukacyjnych osób młodych ${ }^{14}$. Powstaje pytanie: skoro ustawodawca wie o znaczeniu pracy dla dzietności, jak ma zamiar się do tego odnieść w świetle swoich własnych przewidywań (zob. OSR z 29 stycznia 2016), że pod wpływem programu 500+ część kobiet odejdzie z rynku pracy?

Ustawodawca zauważa, że ubóstwa względnego w Polsce doświadcza aż 16\% osób w gospodarstwach utrzymujacych się z pracy najemnej. W świetle tych danych wydaje się szczególnie ważne, aby nie stawiać tych osób przed wyborem pracy lub 500 zł, tylko wzmocnić ich pozycję i wobec państwa, i wobec pracodawcy przez dochód z tych dwóch źródeł. W tym celu należałoby rozważyć podwyższenie progu 800 zł na osobę oraz wprowadzenie mechanizmów tzw. stopniowego wycofywania świadczenia ${ }^{15}$.

\section{Uzgodnienia międzyresortowe}

2 grudnia 2015 r. - czyli dziesięć dni roboczych po exposé premier Szydło - projekt ustawy został przekazany do uzgodnień międzyresortowych. Uwagi do projektu przesłało osiem ministerstw oraz Rządowe Centrum Legislacji. Jedynie Ministerstwo Nauki i Szkolnictwa Wyższego (MNiSW) od-

\footnotetext{
${ }^{14}$ I.E. Kotowska, Niska dzietność w Polsce w kontekście percepcji Polaków, Diagnoza Społeczna, Warszawa 2013.

15 Stopniowe wycofywanie świadczenia (w wersji „złotówka za złotówkę”) oznacza, że świadczenie jest pomniejszone o taką kwotę, o jaką przekroczono próg. Z punktu widzenia wzmacniania pozycji pracownika zarówno względem pracodawcy, jak i względem państwa można by rozważyć ustawienie tzw. taper rate nie na 100\%, ale np. na 70\%, tzn. za 1 zł dodatkowego dochodu, 70 gr świadczenia mniej.
} 
niosło się do celów programu ${ }^{16}$. Minister Gowin napisał: „przesłanką powstania projektu jest zatem aktualny stan związany z demografia, spowodowany różnorodnymi czynnikami”" ${ }^{17}$. Jego głównym zastrzeżeniem jest niespójność między celem a narzędziem. Zauważa, że tak samo jak różnorodne czynniki wpływają na dzietność, tak samo działanie, które na nią odpowiada, musi być wszechstronne i komplementarne. Uważa, że projekt może być „niewystarczajacy do osiagnięcia celu, jakim jest znacząca poprawa sytuacji demograficznej Polski”. Jednocześnie zaznacza, że świadczenie „może przyczynić się do utrwalenia ekskluzji społecznej i dezaktywizacji zawodowej gorzej sytuowanych obywateli” - czyli de facto pogłębiać ubóstwo, które projekt chciał niwelować.

\section{Konsultacje społeczne}

Po zakończeniu uzgodnień międzyresortowych ustalono miesiąc na konsultacje społeczne. Zaledwie pięć dni roboczych po ich zakończeniu projekt wpłynął do Sejmu ${ }^{18}$. Na stronie Rządowego Centrum Legislacji nie ma żadnych pism zgłoszonych w ramach konsultacji społecznych ${ }^{19}$. Można tam śledzić dialog, jaki urzędnicy prowadzili między sobą, a następnie zobaczyć trzy puste rubryki: „stanowiska zgłoszone w ramach konsultacji publicznych”, „odniesienie się wnioskodawcy do uwag” oraz „odrębna konferencja z udziałem podmiotów publicznych”. Co więcej, w rubryce „podsumowanie wyników konsultacji” w OSR do ustawy nie ma żadnych wyników konsultacji ${ }^{20}$. Oznacza to, że sposób, w jaki przeprowadzono konsultacje, nie daje żadnych podstaw do analizy celów programu.

\section{Jakie narzędzia oceny przewiduje ustawodawca?}

Z punktu widzenia nauk o zarządzaniu alternatywnym sposobem na ustalenie celów może być zidentyfikowanie kluczowego wskaźnika efektywności (ang. key performance indicator), czyli miernika stopnia realizacji celów organizacji, a następnie wydedukowanie, co jest oczekiwanym celem, którego stopień osiagnięcia jest mierzony. Według twórców programu Rodzina 500+ ewaluacja jej efektów nastapi na podstawie liczby osób korzystających ze

${ }^{16}$ Cztery inne ministerstwa (MSWiA, MF MS i MR) zgłosiły uwagi merytoryczne, ale niełączące się z celem programu, pozostałe instytucje zaś zgłosiły wyłącznie uwagi techniczne, takie jak błędy w obliczeniach.

17 Stanowiska zgłoszone w ramach uzgodnień: uwagi MNiSW, <http://legislacja.rcl.gov.pl/do cs//2/12279566/12326791/12326794/dokument203211.pdf>.

18 Konsultacje trwały do 22 stycznia 2016, projekt zaś wpłynął do Sejmu w poniedziałek 1 lutego 2016 r., <www.sejm.gov.pl/sejm8.nsf/PrzebiegProc.xsp?nr=216>.

19 Rządowe Centrum Legislacji, zakładka „Konsultacje publiczne”, <http://legislacja.rcl.gov. pl/projekt/12279566/katalog/12326791\#12326791>.

20 Projekt ustawy o pomocy państwa w wychowywaniu dzieci z projektami aktów wykonawczych, <http://orka.sejm.gov.pl/Druki8ka.nsf/0/6A2B97FB4F15F393C1257F4D002A61A2/\%24File/216.pdf>. 
świadczenia oraz liczby urodzeń ${ }^{21}$, co sugeruje nadrzędność celu demograficznego.

Zaproponowany sposób oceny jest podwójnie problematyczny. Po pierwsze, formalnym celem ustawy jest pomoc finansowa w wychowaniu dzieci, a nieformalnym - walka z ubóstwem. Rządzący mówią też o inwestycji w kapitał ludzki i o zmniejszeniu liczby osób korzystających z systemu opieki społecznej. Tymczasem nie mamy żadnego wskaźnika mierzącego którąkolwiek z tych koncepcji. Po drugie, nawet jeśli uznamy nadrzędność celu demograficznego, nominalna liczba urodzeń jest złym miernikiem - szczególnie w Polsce, gdzie pula kobiet w wieku rozrodczym dynamicznie się zmienia w wyniku międzypokoleniowych zmian w dzietności. Lepszą miarą byłby współczynnik dzietności (TFR), który wyraża średnią liczbę dzieci, jaka przypadałaby na jedną kobietę w wieku rozrodczym (15-49 lat).

\section{CELE POLITYKI PUBLICZNEJ W PRZEKAZACH MEDIALNYCH}

Cele polityki publicznej rzadko docierają do obywateli przez dokumenty analizowane w pierwszej części artykułu - o wiele częściej za pośrednictwem przekazów medialnych. $\mathrm{W}$ poniższym rozdziale analizowane sa cele programu komunikowane w mediach przez rządzących (tab. 1). Na podstawie funkcji pełnionej $\mathrm{w}$ momencie wejścia ustawy $\mathrm{w}$ życie (11 lutego 2016) identyfikuję sześciu najważniejszych polityków związanych z obozem rzadzącym (prezes partii rządzącej, premier, trzech wicepremierów i prezydent) oraz trzy najważniejsze osoby w ministerstwie odpowiedzialnym za realizację programu (minister oraz dwóch wiceministrów rodziny, pracy i polityki społecznej). Następnie wybieram wyszukiwarkę Google przez wzgląd na jej udział w rynku wyszukiwarek w Polsce $(97,6 \%)^{22}$. Zawężam zakres czasowy wyszukiwania od 2 grudnia 2015 (daty figurujacej w RCL jako początek prac nad projektem) do końca I kwartału 2017 r. i używam formuły wyszukiwania „imię+nazwisko+cel+500plus” oraz „imię+nazwisko+cel+500+”. Wybieram wyłącznie fragmenty osobiście wypowiedziane przez wybranych dziewięciu polityków, pomijajac słowa przypisywane im przez innych. Preferowanym źródłem cytatów jest oficjalne wystapienie na konferencji prasowej. W przypadku gdy wybrana osoba nie wypowiadała się w tej formie na temat celów programu, użyto cytatów z wystapień medialnych i autoryzowanych wywiadów. Gdy znaleziono więcej niż jeden cytat, użyto tego, w którym bezpośrednio występuje słowo „cel”.

${ }^{21}$ Projekt Oceny Skutków Regulacji (2.12.2015), s. 6, <http://legislacja.rcl.gov.pl/docs//2/1227 9566/12326791/12326792/dokument199002.pdf>.

${ }^{22}$ Dane na 2018 r. ze StatCounter <http://gs.statcounter.com/search-engine-market-share/ all/poland>. 


\section{Tabela 1}

Komunikacja medialna celów programu Rodzina 500+ przez najważniejsze osoby w obozie Zjednoczonej Prawicy oraz w MRPiPS

\begin{tabular}{|l|l|}
\hline $\begin{array}{c}\text { Najważniejsze osoby } \\
\text { w obozie Zjednoczonej } \\
\text { Prawicy }\end{array}$ & \multicolumn{1}{c|}{ Wypowiedź } \\
\hline Prezes Jarosław Kaczyński & $\begin{array}{l}\text { „To jest program przede wszystkim przeciwko nędzy, bo czy } \\
\text { będzie miał skutki pronatalistyczne, dziś trudno ocenić. Mam } \\
\text { nadzieję, że będzie, choć podejrzewam, że dopiero program } \\
\text { "Mieszkanie+« naprawdę odegra taką rolę"a }\end{array}$ \\
\hline Premier Beata Szydło & $\begin{array}{l}\text { „To jest program wprowadzony po to, aby Polakom się lepiej } \\
\text { żło. Żeby polskie rodziny miały bezpieczne, godne życie. } \\
\text { I też, żeby się w Polsce więcej dzieci rodziło"b }\end{array}$ \\
\hline $\begin{array}{l}\text { Wicepremier Mateusz } \\
\text { Morawiecki }\end{array}$ & $\begin{array}{l}\text { „Zadłużyliśmy się na dodatkowe 20 miliardów, bo chcemy pro- } \\
\text { mować dzietnośćc }\end{array}$ \\
\hline Wicepremier Jarosław Gowin & $\begin{array}{l}\text { „Do tej pory skutecznie realizowaliśmy cele społeczne }- \\
\text { przede wszystkim fundamentalnie ważny program »Rodzina } \\
500 \text { plus»"d }\end{array}$ \\
\hline Wicepremier Piotr Gliński & $\begin{array}{l}\text { „Celem programu 500 plus jest to, by w Polsce było więcej } \\
\text { urodzeń”e }\end{array}$ \\
\hline Prezydent Andrzej Duda & $\begin{array}{l}\text { „Państwo pomaga rodzinom w wychowaniu dzieci i daje im } \\
\text { wsparcie” }\end{array}$ \\
\hline
\end{tabular}

${ }^{a}$ Polska The Times, 7.10.2016, Kaczyński: Nie powiem, że nie mam z kim przegrać. Nie jestem tak nieostrożny jak Tusk, <http://www.polskatimes.pl/opinie/wywiady/a/kaczynski-nie-powiem-ze-nie-mam-z-kim-przegrac-nie-jestem-tak-nieostrozny-jak-tusk-wywiad,10713526/>.

${ }^{b}$ Polskie radio, Sygnały Dnia, 31 marca 2017 r., rozmowa z premier Beatą Szydło, <http:// www.polskieradio.pl/13/53/Artykul/1746509, Sygnaly-Dnia-31-marca-2017-roku-rozmowa-z-premier-Beata-Szydlo>.

${ }^{c}$ Gazeta Wyborcza, Morawiecki do sympatyków PiS: 500 Plus jest na kredyt (11 lipca 2016), $<$ http://bydgoszcz.wyborcza.pl/bydgoszcz/1,48722,20385433,morawiecki-do-sympatykow-pis-500-plus-jest-na-kredyt.html>.

${ }^{d}$ wPolityce, Jarosław Gowin: „Największym zagrożeniem dla integracji są nieprzemyślane próby federalizacji Europy" (7.09.2016), <https://wpolityce.pl/polityka/307557-nasz-wywiad-jaroslaw-gowin-najwiekszym-zagrozeniem-dla-integracji-sa-nieprzemyslane-proby-federalizacji-europy> .

e TVN24, Gliński: 500 zł na dziecko także dla emigrantów, <http://www.tvn24.pl> (21.12.2015), $<$ http://www.tvn24.pl>, <https://www.tvn24.pl/wiadomosci-z-kraju,3/glinski-o-ustawie-500-darmowych-lekach-i-trybunale-konstytucyjnym,604935.html>.

f Wypowiedź Prezydenta Dudy na uroczystości podpisania ustawy z dnia 11 lutego 2016 r. o pomocy państwa w wychowywaniu dzieci: „Wsparcie państwa dla rodzin to najlepszy wzorzec”, $<$ http://www.prezydent.pl/aktualnosci/wydarzenia/art,122, prezydent-wsparcie-panstwa-dla-rodzin-to-najlepszy-wzorzec.html>. 


\section{Tabela 2}

Komunikacja medialna celów programu Rodzina 500+ przez najważniejsze osoby MRPiPS

\begin{tabular}{|l|l|}
\hline $\begin{array}{c}\text { Najważniejsze osoby } \\
\text { odpowiedzialne za program } \\
\text { w MRPiPS }\end{array}$ & \multicolumn{1}{c|}{ Wypowiedź } \\
\hline Minister Elżbieta Rafalska & $\begin{array}{l}\text { „Przyświecają mu trzy główne, równorzędne cele: zwiększenie } \\
\text { wskaźnika dzietności, inwestycja w kapitał ludzki, redukcja } \\
\text { biedy wśród najmłodszych Polaków”a. „Jednym z celów jest to, } \\
\text { aby część rodzin wyszła z systemu pomocy społecznej”” }\end{array}$ \\
\hline Wiceminister Stanisław Szwed & $\begin{array}{l}\text { „Ten program ma cel długofalowy. Zakładaliśmy, że wskaźnik } \\
\text { dzietności wzrośnie w ciagu 10 lat do 1,6 albo nawet 1,7”c }\end{array}$ \\
\hline Wiceminister Bartosz Marczuk & $\begin{array}{l}\text { „Program 500+ ma trzy równorzędne cele. Pierwszy to działanie } \\
\text { pronatalistyczne, które ma sprawić, że zwiększy się liczba uro- } \\
\text { dzeń. Drugi - inwestycji w kapitał ludzki [...]. Trzeci cel to re- } \\
\text { dukcja biedy, a w zasadzie nędzy wśród najmłodszych Polaków”d }\end{array}$ \\
\hline
\end{tabular}

${ }^{a}$ Wystapienie Elżbiety Rafalskiej, Minister Rodziny, Pracy i Polityki Społecznej podczas pierwszego czytania rządowego projektu ustawy o pomocy państwa w wychowywaniu dzieci, w dniu 9 lutego 2016 r., <https://www.mpips.gov.pl/wsparcie-dla-rodzin-z-dziecmi/rodzina-500-plus/dokumenty-i-opracowania/wystapienie-elzbiety-rafalskiej-minister-rodziny-pracy-i-polityki-spolecznej-podczas-pierwszego-czytania-rzadowego-projektu-ustawy-o-pomocy-panstwa-w-wychowywaniu-dzieci-/>.

${ }^{b}$ Konferencja prasowa: Rodzina 500+ Elżbieta Rafalska, Elżbieta Witek, Beata Szydło, Henryk Kowalczyk, <https://www.youtube.com/watch?v=b8CkOgip_3Y>.

${ }^{c}$ Radio Maryja, S. Szwed: program 500 plus ma swój długofalowy cel, 5 kwietnia 2017, http:// www.radiomaryja.pl/informacje/s-szwed-program-500-plus-swoj-dlugofalowy-cel/.

${ }^{d}$ Dziennik, Wiceminister od 500+. Bartosz Marczuk: Oczywiście, że wezmę pieniądze z programu (1.04.2016), Wywiad dla <http://wiadomosci.dziennik.pl/opinie/artykuly/517027, wiceminister-bartosz-marczuk-program-rodzina-500-plus-magdalena-rigamonti-wywiad.html>.

Źródło: opracowanie własne.

W wypowiedziach dziewięciu polityków Zjednoczonej Prawicy można wyróżnić siedem celów: ogólną walkę z ubóstwem, walkę z ubóstwem dzieci, „godne życie”, podwyższanie dzietności, zmniejszanie kosztów wychowania, inwestowanie w kapitał ludzki i zmniejszenie liczby osób w systemie pomocy społecznej. Minister Rafalska i wiceminister Marczuk wskazywali na cele równorzędne, inni je hierarchizowali. Część polityków spodziewała się przeciwstawnych efektów: wiceminister Szwed założył wzrost współczynnika dzietności z 1,3 do 1,6-1,7 (co w demografii jest spektakularnie wielką różnica), tymczasem prezes Kaczyński, który przestawił się jako pomysłodawca programu $^{23}$ - nie spodziewał się efektów pronatalistycznych, ale to nie one są najważniejsze, program bowiem jest „przede wszystkim przeciwko nędzy”. Ciekawego zestawienia dostarcza wicepremier Gowin, który w mediach powiedział, że program skutecznie realizuje cele społeczne. Jednocześnie w trak-

${ }^{23}$ Polska The Times, Kaczyński: Nie powiem, że nie mam z kim przegrać. Nie jestem tak nieostrożny jak Tusk, <http://www.polskatimes.pl/opinie/wywiady/a/kaczynski-nie-powiem-ze-nie-mam-z-kim-przegrac-nie-jestem-tak-nieostrozny-jak-tusk-wywiad,10713526/>. 
cie uzgodnień międzyresortowych uznał program za utrwalający ekskluzję społeczną niezamożnych i za niewystarczający do osiagnięcia celu, jakim jest znacząca poprawa sytuacji demograficznej Polski.

\section{Schemat 2}

Cele programu Rodzina 500+ według dokumentów legislacyjnych, wypowiedzi medialnych oraz sposobu ewaluacji
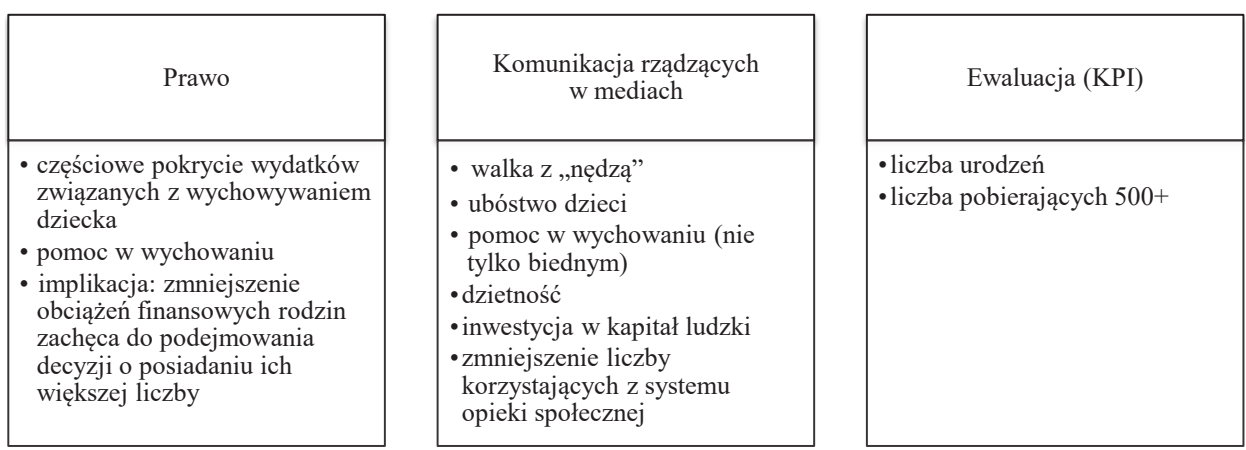

Trzy sposoby wyznaczenia celów polityki publicznej wskazują na odmienne i potencjalnie niespójne ze sobą cele (schemat 2). W legislacji występuje przede wszystkim pomoc w wychowaniu oraz założenie, że obniżenie kosztów wychowania dzieci doprowadzi do zwiększenia ich liczby. W komunikacji medialnej występuje siedem celów: od walki z „nędzą” po inwestycje w kapitał ludzki. Z kolei ze sposobu ewaluacji da się wydedukować wyłącznie cel demograficzny.

\section{POLITYKA PARTYJNA: NIEWYPOWIEDZIANE CELE PROGRAMU}

Posunięcia, które wydają się niespójne z punktu widzenia polityki publicznej, mogą mieć sens z punktu widzenia polityki partyjnej. Kluczowe są trzy wątki: jasność versus elastyczność celu, usprawnianie istniejących systemów versus budowanie nowych oraz partia versus państwo jako gwarant ich kontynuacji.

Po pierwsze, im bardziej precyzyjny cel, tym łatwiej rządzących z niego rozliczyć i podać w wątpliwość narzędzie zastosowane do jego osiagnięcia. Gdyby celem była wyłącznie redukcja skrajnego ubóstwa dzieci, można by go osiagnąć osiem razy taniej ${ }^{24}$. Gdyby celem była wyłącznie wyższa dzietność, wymagałoby to bardziej skomplikowanego policy mix - łączącego transfery z rozbudowa infrastruktury opiekuńczej i zmianami na rynku pracy, które sa trudniejsze do przeprowadzenia, a ich efekty widzimy z opóźnieniem, co utrudnia wskazanie na autora ewentualnego sukcesu. Mówienie, że celem 500+ jest „pomoc finansowa” ociera się o tautologię (gdyż 500+ jest pomocą finansowa, której celem jest pomoc finansowa). Podobnie brzmi beckerowskie „inwestowa-

${ }^{24}$ M. Brzeziński, M. Najsztub, Wptyw programu „Rodzina 500+” na dochody gospodarstw domowych, ubóstwo i nierówność, 2016, s. 19, <http://coin.wne.uw.edu.pl/mbrzezinski/research/ rodzina500plusPolitykaSpoleczna_nowa_wersja.pdf>. 
nie w kapitał ludzki”, które przez rządzących jest interpretowane tak szeroko, że przeznaczenie pieniędzy na niemal dowolny cel staje się „inwestycją. Wiceminister rodziny jako przykład inwestycji podaje np. kupno wielkogabarytowych dóbr, edukację, oszczędzanie czy spłatę długów ${ }^{25}$. Jest to mieszanie tak różnych kategorii w ekonomii, jak: konsumpcja, inwestycja, oszczędności czy redukcja zobowiązań. Wielość i niedookreśloność celów sprawia, że nie można ich rozliczyć. Program jest przez to bezpieczniejszy politycznie, ponieważ w przypadku braku sukcesu (np. niezmienionego poziomu dzietności) można zwrócić uwagę na pozostałe cele, zwłaszcza na ogólne „inwestowanie w kapitał ludzki”, które w formie zaprezentowanej przez wiceministra jest niefalsyfikowalne. W tej konwencji ewaluacji programu dokonał już prezydent Duda, mówiąc, że program działa, dlatego że „wielu ludzi wygląda dzisiaj lepiej”26.

Po drugie, wielość i niejasność sformułowanych celów pozwala odwrócić uwagę od faktu, że w systemie polityki społecznej już istnieją instrumenty o zbliżonych funkcjach - nawet jeśli sa one dalece niedoskonałe. Uznanie, że realizowany cel jest kontynuacja - a nie nowością w systemie wsparcia rodzin i walki z ubóstwem - wymusiłoby uporządkowanie systemu i wpisanie nowego świadczenia do instrumentów już istniejących. Obecnie istnieją: zasiłek rodzinny, świadczenia opiekuńcze, zapomoga wypłacana przez gminy, świadczenie wypłacane przez gminy. Do tego dochodzą różnego rodzaju dodatki do zasiłku rodzinnego, ulgi na dzieci w PIT, a od 2016 r. - Rodzina 500+. System świadczeń rodzinnych (ustawa z 28 listopada 2003) ustanowił progi dochodowe na 674 zł, 764 zł czy 1922 zł, z kolei ustawa o pomocy uprawnionym do alimentów precyzuje próg 725 zł. Rodzina 500+ nie tylko nie porządkuje zastanego chaosu, ale go zwiększa przez ustanowienie nowych progów 800 zł i 1200 zł na osobę - niepowiązanych z tym, co dotychczas uznawano za granicę prawa do skorzystania ze świadczeń. Nowy instrument o niejasnym celu pozwala na stworzenie równoległego, niezależnego prawnie i wizerunkowo systemu ze szkodą dla spójności polityki państwa, ale z pożytkiem dla polityki partyjnej, w której jest prezentowany jako pomysł spektakularny i bezprecedensowy.

Po trzecie, program Rodzina 500+ charakteryzuje bardzo wysokie poparcie współistniejące z niewiarą w jego kontynuację ${ }^{27}$. W marcu 2017 r. program popierało $77 \%$ Polaków (w tym $37 \%$ zdecydowanie), a $20 \%$ wyrażało dezaprobatę. Zwolennicy programu dominowali w każdej z grup demograficznych ${ }^{28}$. Jednakże tylko 35\% uprawnionych do świadczenia na jedno dziecko i $39 \%$ uprawnionych do świadczenia na co najmniej dwoje dzieci wierzy, że program

${ }^{25}$ „Marczuk o 500+: Wartość republikańska”, 1.01.2017, <http://www.rp.pl/Publicystyka/ 301019941-Marczuk-o-500-Wartosc-republikanska.html>.

${ }^{26}$ Dosłowny cytat: „Program 500+ jest widoczny. Może trudno jest go na co dzień zauważyć, ale on naprawdę spowodował, że wielu ludzi wygląda dzisiaj lepiej”. Rzeczpospolita, Prezydent: efekty programu 500 Plus są widoczne (11.02.2017), <http://www.rp.pl/Dane-gospodarcze/ 302119954-Prezydent-efekty-programu-500-Plus-sa-widoczne.html>.

${ }^{27}$ Wszystkie dane na temat kontynuacji programu pochodzą z CBOS, Program „Rodzina 500 plus" jako element systemu wspierania rodzin i dzietności. Komunikat z Badań nr 25/2016, Warszawa 2016.

${ }^{28}$ CBOS, Ocena programu „Rodzina 500 plus” po blisko roku od jego wprowadzenia. Komunikat z Badań nr 36/2017, Warszawa 2017. 
będzie kontynuowany. Odpowiednio 49\% i 47\% sądzi, że zostanie wycofany, a reszta nie ma zdania. Co istotne, wiara w kontynuacje programu jest najniższa wśród młodych ludzi (18-34 lata), czyli w tej grupie, od której poziom przyszłej dzietności będzie zależał najbardziej. Aż 60\% grupy wiekowej 18-24 i 63\% grupy wiekowej 25-34 uważa, że program będzie wycofany. Niewiara w kontynuację źle wróży celom dzietnościowym tej polityki publicznej, ale wróży dobrze postrzeganiu obozu Prawa i Sprawiedliwości jako jej gwaranta. Z tego punktu widzenia jednym z niepisanych celów programu 500+ może być utrzymywanie poparcia politycznego zogniskowanego na PiS jako na gwarancie polityki cieszącej się dużą popularnością. Najlepiej wyrażają to słowa premier Szydło: „jeżeli ocenią wyborcy, że jest to program, który jest godny tego, aby był kontynuowany, to myślę, że oddadza głos na Prawo i Sprawiedliwość, dlatego że ja nie widzę w tej chwili innego ugrupowania w Polsce, które byłoby zainteresowane kontynuowaniem 500+" 29 .

Schemat 3

Polityka publiczna a polityka partyjna
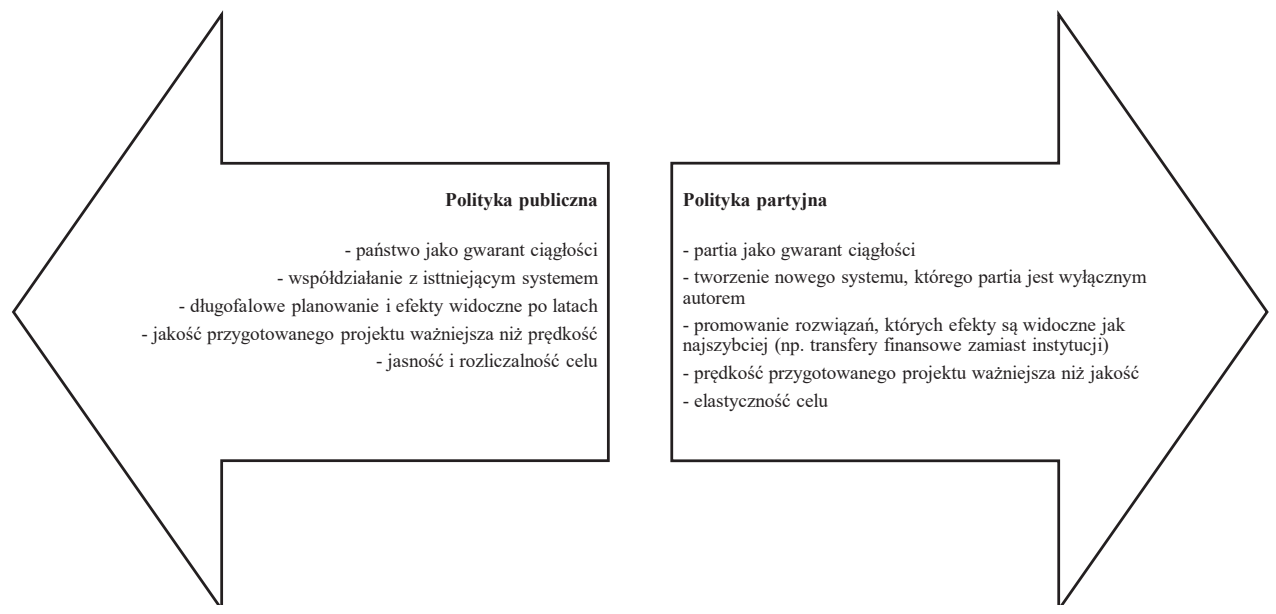

Źródło: opracowanie własne.

\section{PODSUMOWANIE}

W legislacji jako cel programu Rodzina 500+ wymienia się: pomoc finansową dla rodzin wychowujacych dzieci; przeciwdziałanie „spadkowi demograficznemu” i częściowe pokrycie wydatków związanych z wychowywaniem dziecka. Na podstawie wypowiedzi polityków PiS można wyróżnić siedem celów: przeciwdziałanie „nędzy”, zmniejszenie ubóstwa dzieci, podwyższanie dzietności,

${ }^{29}$ Polskie radio, Sygnały Dnia, 31 marca 2017 r., rozmowa z premier Beatą Szydło, <http:// www.polskieradio.pl/13/53/Artykul/1746509, Sygnaly-Dnia-31-marca-2017-roku-rozmowaz-premier-Beata-Szydlo>. 
zmniejszanie kosztów wychowania, inwestowanie w kapitał ludzki, zmniejszenie liczby osób w systemie pomocy społecznej i „godne życie”. Przewidziany zaś sposób ewaluacji polityki publicznej - oparty wyłącznie na liczbie nowo narodzonych dzieci i liczbie beneficjentów programu - sugeruje, że celem programu jest wyższa dzietność.

Z punktu widzenia jakości polityki publicznej słabościa programu jest brak konsekwencji co do tego, co program zamierza osiagnać. Sprawia to, że zarówno skuteczność, jak i opłacalność polityki sa niemożliwe do ocenienia, gdyż nie jest jasne, co byłoby sukcesem. Jednakże z punktu widzenia polityki partyjnej rozległe i elastyczne cele są bezpieczniejsze politycznie i skuteczniejsze wizerunkowo.

Cele polityki publicznej i polityki partyjnej nie muszą być ze sobą sprzeczne - posiadanie legitymacji do sprawowania władzy, jest warunkiem prowadzenia polityki publicznej, a to, co utrzymuje partię przy władzy, może być równocześnie pożądane z punktu widzenia polityki publicznej. Rodzina 500+ może mieć pozytywne skutki z tego drugiego punktu widzenia (np. zmniejszać ubóstwo) i jednocześnie konserwować poparcie PiS. Jednak sposób jej wprowadzenia dostarcza przykładu na wykluczające się wartości (schemat 3). Żadna polityka publiczna nie istnieje w społeczno-ekonomicznej próżni, a program Rodzina 500+ przez swój koszt (22 mld złotych rocznie), zasięg (2,4 ml rodzin), poparcie społeczne (77\%) i wolę polityczną miał jeszcze większe szanse na osiagnięcie synergii z innymi politykami publicznymi. Presja czasu, pod którą tworzono program, negatywnie wpłynęła na jego jakość: od niejasności celów, przez niedostosowanie narzędzi, po brak komplementarności w systemach wsparcia rodzin i fasadowe konsultowanie rozwiązań.

mgr Anna Gromada

Instytut Filozofii i Socjologii Polskiej Akademii Nauk

Warszawa

agromada@ifispan

WHAT IS THE PURPOSE OF THE 'FAMILY 500+' PROGRAMME?

AN ANALYSIS OF THE PUBLIC POLICY AND PARTY POLICY OBJECTIVES

Summary

The paper analyses the legislation, media communication and the planned evaluation of the 'Family 500+" Programme conducted in order to identify its goals as part of the public policy. Seven identified goals have been compared with the objectives of Poland's leading party's politics. From the public policy viewpoint, due to unclear goals of the programme, its effectiveness and efficiency are impossible to assess. Yet, from the party's politics perspective, the transfer is well-calibrated to be politically safe with the ruling party serving as its guarantor. 